\title{
The Role of Cooperative Association in Providing the Agricultural Services in the Governorate of Unaizah - Kingdom of Saudi Arabia
}

\author{
Abdullah A. Alzaidi ${ }^{1}$, Mirza B. Baig ${ }^{1 *}$, Hazem S. Kassem ${ }^{1}$ and Muhammad Abubakar Zia ${ }^{1}$ \\ Date Received: $13^{\text {th }}$ January 2020 / Date Accepted: 06 ${ }^{\text {th }}$ March 2020
}

\begin{abstract}
Purpose: Generally Cooperative Associations play positive and productive role in disseminating the latest information on all aspects and services to the farming communities. However, it seemed imperative to assess the perceptions of the members and evaluate role of the Unaizah Agricultural Cooperative Association (UACA) to improve its working by addressing the issues and concerns of its members.

Research Method: One hundred thirty-two respondents representing 25\% of registered member farmers of the association were identified by applying a random sampling technique. Data were collected by using a welldesigned and pre-tested questionnaire to achieve the objectives of the study. Descriptive statistics were used to analyze and interpret the data.

Findings : Respondents had high perceptions regarding the role of UACA in the following areas: makes agricultural innovations available to the farmers at suitable prices; establishes good contacts with extension staff; brings useful activities; helps solving agricultural problems; provides timely information; maintains good relations with its members; establishes beneficial agreements with traders to enable farmers to have easy access to markets. Though majority (70.5\%) of the respondents were highly aware of the importance of the association yet almost half of the respondents (53\%) were moderately satisfied, suggesting an improvement in its working.
\end{abstract}

Originality/Value : No scientific study of the kind has not been launched before. Hence the outcomes of the study would help the association in enhancing its working.

Keywords: Cooperatives, Farmers 'perceptions; issues; Policy makers; Extension Service; Improvement measures

\section{INTRODUCTION}

The Kingdom of Saudi Arabia spreads over an area of 2,149,690 square kilometers, with a population of 32.5 million. Agriculture in the Kingdom of Saudi Arabia contributes 5.2\% to the Gross Domestic Product (GDP), with a total of 52 billion Saudi Riyals (General Authority for Statistics, 2018). The Kingdom attaches great importance to its agriculture and its share towards food security. The Al-Qassim region, due to its significant potential and productive role towards the overall agricultural sector in the Kingdom of Saudi Arabia, has received much attention from the government and resultantly has witnessed rapid development. More than two million hectares of uncultivated land has been given to the farmers, free of charge, along with free water, low-cost fuel and electricity, and duty-free imports of raw material and machinery. Moreover, the government subsidizes $45 \%$ of agricultural equipment cost and $50 \%$ of fertilizer prices; it also provides interest-free loans (Fiaz et al., 2018).

Different organizations are working in the Kingdom of Saudi Arabia to serve farmers by making agricultural inputs and supplies available to them (e.g., pesticides, fertilizers, machinery, seeds, etc.) and disseminating agricultural information under the policy

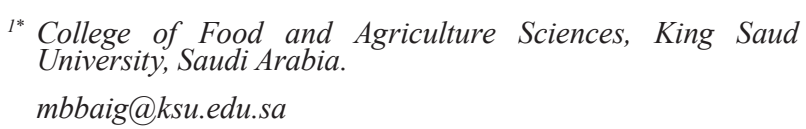
mbbaig@ksu.edu.sa

D ORCID http://orcid.org/0000-0001-7879-3117 
of the Ministry of Environment, Water, and Agriculture (MEWA). These providers include governmental extension services, the private sector (agricultural companies and private consultants), and Cooperative Associations (Kalim, 2014).

Encouraging farmers to act collectively is seen as one of the most viable strategies for addressing constraints, especially for small farmers (Shiferaw et al., 2006). Experiences gained globally indicate that co-operatives are among the institutional arrangements that can help small farmers improve productivity as well as enhance options for marketing their produce (Birthal et al., 2005). Clegg, (2006) is of the opinion that the cooperatives help small farmers to survive when the markets are highly competitive and fluctuating. They assist farmers when the transaction costs are high. They also facilitate the farmers fetching the highest prices by selling their produce collectively while meeting the high demands.

In this regard, the Government of Saudi Arabia has recognized farmer-controlled co-operatives as an instrument of change that can effectively reduce transaction costs, increase farmer productivity, and enhance market participation by smallholder farmers (Al-Oifi, 2012). Consequently, policies have been drafted for the development of co-operatives to encourage the birth of more producer organizations. The total number of cooperatives registered in the Kingdom of Saudi Arabia reached 233 in 2018 (Ministry of Labor and Social Development, 2018). The Unaizah Agricultural Cooperative Association (UACA) is one of the agricultural cooperatives located in the Al-Qassim region. It was established on June 22, 1964, as a statutory corporation under MEWA. The main functions of this Cooperative society are marketing, processing and storing agricultural produce; distributing agricultural machinery, seeds, pesticides, fertilizers, and other inputs; and assisting its members with timely technical advice in agricultural production (Unaizah Agricultural Cooperative, 2018).

The role of cooperatives is not only to focus on promoting business and increasing profit margins but also to meet the agricultural needs of their members (Kodama, 2009). Hence, farmers' access and satisfaction toward agricultural services is a critical factor to gauge the performance of cooperatives. Diversity and quality of the agricultural services are the main indicators for satisfaction (Ganpat et al., 2014). The present study investigates the satisfaction levels of the respondents toward the UACA.

\section{Statement of the Problem}

Small-scale farmers can increase their productivity and income by collectively negotiating better prices for inputs like seeds, fertilizers, and transport through cooperatives. Though different studies have been performed in the Kingdom of Saudi Arabia on the performance and effectiveness of agricultural cooperatives, no one has focused on assessing the role of the UACA. The perceptions of the members on the role of UACA in providing agricultural services and level of members' satisfaction towards these services require further investigation. The study assumes that satisfaction of the members towards the quality of services offered by the cooperatives will determine the future success of cooperative associations. This study, therefore, explores the members' level of access for and satisfaction with agricultural services provided by the UACA.

\section{Objectives of the Study}

The specific objectives of the study are:

1. To identify the perception of farmers regarding the role of Unaizah Agricultural Cooperative Association in agricultural development.

2. To assess the members' level of satisfaction with the agricultural services provided by the Unaizah Agricultural Cooperative Association.

\section{Significance of the Study}

Unaizah Agricultural Cooperative Association (UACA) has an important place in the agricultural sector, especially in the study area. The farming community of the area is involved in collective action in purchasing input supplies 
from and selling produce to the market. The information to be obtained from this study about farmers' perceptions and satisfaction towards services provided will generate useful information and knowledge that can assist the board members of the cooperative. This study investigates areas requiring intervention or adjustments that will improve the satisfaction of UACA members. Moreover, policy-makers can use this knowledge as a guide in developing needed legislation and providing economic support for agricultural cooperatives. The agricultural extension service could benefit from exploring the perception of members in planning awareness programs to increase farmer knowledge about the role of cooperatives in achieving sustainable rural development.

\section{Scope of the Study}

The findings of the study are based on the information expressed by the respondents regarding perception and satisfaction of the UACA. This study is limited to members of the UACA, but the findings may be applicable and beneficial to other cooperatives and organizations working in similar functions and services in the Kingdom of Saudi Arabia.

\section{RESEARCH METHODOLOGY}

\section{Study Area and Population}

Survey methodology was adopted for data collection from the member farmers of the UACA to meet the objectives of the study. The research was conducted in the Governorate of Unaizah which is in the Al-Qassim Region. It lies in south of Buraydha and north of Riyadh - the capital. It is the second largest region of Al-Qassim with a population of 163,729 (Wikipedia, 2017).

The UACA was developed in 1964 and registered with the Ministry of Labor and Social Affairs. It provides agricultural services such as agricultural equipment, seeds, pesticides, warehouse facilities, irrigation services, and marketing to its 528 registered members (Unaizah Agriculture Cooperative Association, 2018).

\section{Sample size and Data Collection}

A random sample of 132 respondents representing $25 \%$ of registered member farmers of the Unaizah Agricultural Cooperative Association (UACA). was drawn to collect data. In order to achieve the objectives of the study, a questionnaire was initially developed in English. However, for the ease of data collection and essential information, the questionnaire was translated into local, simple and plain language (Arabic), possibly avoiding scientific and technical terms. The validity and reliability of the interview schedule were pretested on 20 respondents. As a result of pretesting, necessary amendments were made and incorporated to give the questionnaire its final shape. Cronbach's Alpha was calculated ( $\alpha=$ 0.84 ) to check the reliability of the perception scale.

This survey consists of three sections. The first section includes socio-economic attributes (age, education level, farming experience, farm size and membership duration with the UACA). The second portion includes members' perceptions of the agricultural services provided by the UACA. The third section addresses the role of the UACA towards the provision of the agriculture services to the members and satisfaction level of such service.

\section{Data Analysis}

Data were analyzed using the Statistical Package for Social Sciences (SPSS). Descriptive statistics, frequency distributions, percentages, means and standard deviations were used to analyze the data. All answers were recorded using a Likert scale of $1=$ low, $2=$ moderate, and $3=$ high.

\section{RESULTS AND DISCUSSION}

\section{Socio-economic profile of the respondents}

\section{Age of the respondents}

Figure 01a. shows the age of the respondents. The findings revealed that the majority of respondents (64\%) were middle-aged (between 
40 to 60 years), followed by $18 \%$ of the respondents who were less than 40 years old and $18 \%$ more than 60 years old. Mature farmers might have a long history of participating in activities of the UACA which might positively affect their perception and satisfaction for the services provided.

\section{Education Level}

As demonstrated by Figure $01 b ., 39 \%$ of the respondents had a middle-school education, $35 \%$ received secondary education and $18 \%$ of respondents had a primary education. Only $5 \%$ of the respondents were illiterate, while $3 \%$ of them had higher education. The majority of the respondents were not very well-educated as revealed by the study. It seems that educated respondents might have more knowledge on the role of UACA in the Governorate of Unaizah.

\section{Main Occupation}

Figure 01c. presents the occupations of the respondents. Almost one-half $(48 \%)$ of the respondents were associated with the agricultural sector and other businesses, followed by 35\% who were engaged with only agriculture, and $17 \%$ who were part-time engaged in agriculture. Respondents had a high interest in agriculture, which might be a positive factor in seeing an important role of the UACA in agricultural development.

\section{Land Size}

An overwhelming majority of the respondents (98\%) owned less than 20 hectares of agricultural land and only $2 \%$ owned 20-40 hectares, as seen in Figure $01 \mathrm{~d}$. The vast majority of the respondents were small-scale farmers. Smallscale farmers might have a motivation to engage themselves actively with the UACA and realize the benefit of the agricultural services it provides.

\section{Agricultural Experience}

Figure 01e. shows the agricultural experience of the respondents. More than two-thirds (70\%) of the respondents had more than 20 years of farming experience, while $22 \%$ of them had 10 to 20 years of farming experience. Only $9 \%$ of the respondents had less than 10 years of farming experience. Farming experience might have a positive effect on a farmer's technical efficiency, so they might have more technical knowledge about the services needed on their farms.

\section{Membership Duration}

The duration of the respondents' membership in the UACA is depicted in Figure (1f). The majority of respondents $(66 \%)$ had been members for more than 20 years, whereas $17 \%$ had been members for less than 10 years and $17 \%$ were members from 10 to 20 years. Longer membership in the UACA might reflect more positive perceptions on its benefits to members.

\section{Members' Perception of the role of Unaizah Cooperative Association in Agricultural development}

Farmers expressed high agreement with eight statements about the role of the UACA in agricultural development, whereas the other seven statements received moderate agreement from the respondents (Table 01). The main areas with the high agreement included: makes agricultural innovations available to the farmers at suitable prices (Mean 2.97; SD 0.70); establishes good agreements with governmental extension staff for extension services (Mean 2.84; SD 0.38); the activities of the Cooperative are open for all farmers in the area (Mean 2.73; SD 0.49); solves members' agricultural problems (Mean 2.67; SD 0.51); makes agricultural information available to the farmers at the appropriate and right time (Mean 2.61; SD 0.53); establishes good relations with the members (Mean 2.59; SD 0.56); makes good agreements with the traders to buy crops from the members of the cooperative (Mean 2.45 ; SD 0.52) and helps members to have easy access to the markets (Mean 2.44 ; SD 0.65). These results are in line with the findings of Dakurah et al., (2005), as they also found that the farming community in Alberta (Canada) had a high perception of the agricultural services provided by the cooperative and $93 \%$ of the respondents mentioned that their cooperative performed well. 

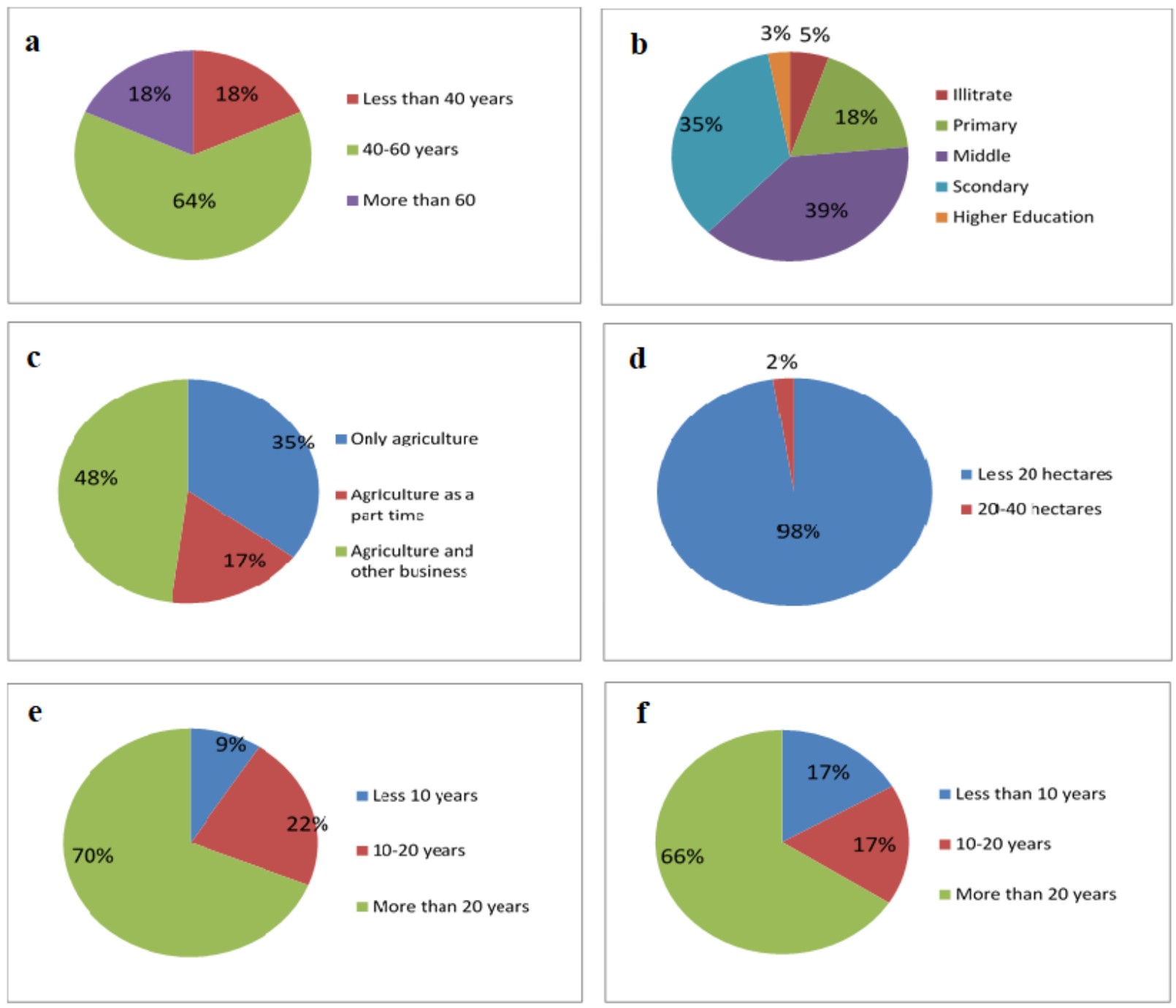

Figure 01: Socio economic features of the respondents; a. Age of the respondents; b. Education level of the respondents; c. Main occupation of the respondents; d. Area under cultivation; e. Farming experience in years; $f$. Membership duration of the respondents

On the other hand, respondents exhibited moderate agreement on other issues such as the inability of management to include the members in the decision making process, training and education of the farmers, and other statements as revealed in Table 01. A possible reason for these lower scores could be the low participation of members in regular meetings organized by the UACA.

Argaw (2007) views cooperatives as economic enterprises and as self-help organizations that play a meaningful role in improving the socioeconomic conditions of their members and the local communities. Over the years, cooperative enterprises have successfully operated locallyowned people-centered businesses and have also served as catalysts for social organization and cohesion. The social role of cooperatives is promoted through voicing common goals, enhancing participation in value chains, and protecting producers from unfair pricing. Cooperatives also create an opportunity for networking and working in partnership with other agencies.

A study conducted in Sudan demonstrated that private farmers are significantly different perceptions than the members of agricultural cooperative regarding the effectiveness of different extension information channels. The evaluation by private farmers regarding the effectiveness of extension information sources is more positive than that of agricultural cooperative members. Private farmers could have more access to the different extension information channels which were investigated (Mohamed, 2006). 
Table 01: Members' perceptions about the role of Unaizah Agricultural Cooperative Association in agricultural development

\begin{tabular}{|c|c|c|c|c|c|c|c|c|c|}
\hline \multirow{3}{*}{ Statements } & \multicolumn{6}{|c|}{ Perception level } & \multirow{3}{*}{ Mean } & \multirow{3}{*}{ SD } & \multirow{3}{*}{ Rank } \\
\hline & \multicolumn{2}{|c|}{ High (3) } & \multicolumn{2}{|c|}{ Moderate (2) } & \multicolumn{2}{|c|}{ Low (1) } & & & \\
\hline & $f$ & $\%$ & $f$ & $\%$ & $f$ & $\%$ & & & \\
\hline $\begin{array}{l}\text { The agricultural cooperative supplies agricultural } \\
\text { innovations at the suitable prices to the farmers }\end{array}$ & 128 & 97 & 4 & 3.0 & 0.0 & 0.00 & 2.97 & 0.7 & 1 \\
\hline $\begin{array}{l}\text { The agricultural cooperative has established good } \\
\text { agreements with the governmental extension staff to benefit } \\
\text { the extension services like collective field demonstrations }\end{array}$ & 112 & 84.8 & 19 & 14.4 & 1.0 & 0.8 & 2.84 & 0.38 & 2 \\
\hline $\begin{array}{l}\text { The agricultural cooperative makes its activities to all the } \\
\text { farmers in the area }\end{array}$ & 100 & 75.8 & 29 & 22.0 & 3 & 2.3 & 2.73 & 0.49 & 3 \\
\hline $\begin{array}{l}\text { Cooperative helps in solving the agricultural problems } \\
\text { faced by its members }\end{array}$ & 92 & 69.7 & 37 & 28.0 & 3 & 2.3 & 2.67 & 0.51 & 4 \\
\hline $\begin{array}{l}\text { The agricultural cooperative provides agricultural } \\
\text { information at the appropriate times to the farmers }\end{array}$ & 83 & 62.9 & 46 & 34.8 & 3.0 & 2.3 & 2.61 & 0.53 & 5 \\
\hline $\begin{array}{l}\text { Most of the farmers in the area enjoy good relations with } \\
\text { the agricultural cooperative }\end{array}$ & 83 & 62.6 & 44 & 33.3 & 5 & 3.8 & 2.59 & 0.56 & 6 \\
\hline $\begin{array}{l}\text { The agricultural cooperative has established good } \\
\text { agreements with traders to buy the crops of the farmers }\end{array}$ & 61 & 46.2 & 69 & 52.3 & 2.0 & 1.5 & 2.45 & 0.52 & 7 \\
\hline $\begin{array}{l}\text { Cooperative helps farmers to have easy access to the } \\
\text { markets }\end{array}$ & 70 & 53.0 & 50 & 37.9 & 12 & 9.1 & 2.44 & 0.65 & 8 \\
\hline $\begin{array}{l}\text { The agricultural cooperative has established working } \\
\text { agreements with the input providers to buy far inputs at } \\
\text { the low prices }\end{array}$ & 61 & 46.2 & 55 & 41.7 & 16 & 12.1 & 2.34 & 0.68 & 9 \\
\hline $\begin{array}{l}\text { The governing board of agricultural cooperative has good } \\
\text { managerial and financial capabilities }\end{array}$ & 33 & 25.0 & 84 & 63.6 & 15 & 11.4 & 2.14 & 0.59 & 10 \\
\hline $\begin{array}{l}\text { The Cooperative has diversified activities in all fields of } \\
\text { agriculture }\end{array}$ & 33 & 25.0 & 73 & 55.3 & 26 & 19.7 & 2.05 & 0.66 & 11 \\
\hline $\begin{array}{l}\text { Cooperative empowers farmers to have improved quality } \\
\text { of life and enables them to more economic opportunities } \\
\text { through self-help }\end{array}$ & 16 & 12.1 & 88 & 66.7 & 28 & 21.2 & 1.91 & 0.57 & 12 \\
\hline $\begin{array}{l}\text { The cooperative provides the required agricultural inputs } \\
\text { and information at suitable times when the farmers need } \\
\text { them in the production process }\end{array}$ & 17 & 12.9 & 84 & 63.6 & 31 & 23.5 & 1.89 & 0.59 & 13 \\
\hline $\begin{array}{l}\text { Trainings provided by the cooperative are helpful and } \\
\text { responsive to the needs of the members }\end{array}$ & 15 & 11.4 & 83 & 62.9 & 34 & 25.8 & 1.86 & 0.59 & 14 \\
\hline $\begin{array}{l}\text { Most members actively participate in the activities of } \\
\text { agricultural cooperative }\end{array}$ & 22 & 16.7 & 66 & 50.0 & 44 & 33.3 & 1.83 & 0.69 & 15 \\
\hline
\end{tabular}

Source: Field survey, 2018

Members' level of access to the services provided by Unaizah Agricultural Cooperative

Findings on the access level to services provided by the UACA are shown in Table 02. Farmers had the easiest and readiest access to seeds (Mean 3, SD 0.00), followed by veterinary pharmacy services (Mean 2.99, SD 0.08), pesticides (Mean 2.98, SD 0.12), irrigation supplies, chemical fertilizers, training sessions on micro-nutrients, and animal feed additives. The respondents have moderate assess to such services as refrigerated trucks, farm products handling, pesticide residue testing, new agricultural information, workshops/ seminars, and agricultural machinery. Table 02 also reveals that farmers had low or no access to the following services: information on the marketing of agricultural produce, festivals, cold storage and loan facilities.

Mohamed (2004) confirmed that agricultural cooperative members have significantly higher access to land preparation services, supplies of improved seeds, irrigation, transportation, credit, storage, and marketing services. The constraints faced by the cooperatives include lack of access to finance, lack of professional management, misappropriation of funds, low commitment and participation by members, lack of timely market information, and a high price for agricultural inputs. The author also maintains that when the famers lack trust in the cooperatives that results in the poor quality of services provided by them. 
Table 02: $\quad$ Famers access towards the agricultural services provided by Unaizah Agricultural Cooperative Association (UACA)

\begin{tabular}{|c|c|c|c|c|c|c|c|c|c|}
\hline \multirow{3}{*}{ Services } & \multicolumn{6}{|c|}{ Access level } & \multirow{3}{*}{ Mean } & \multirow{3}{*}{ SD } & \multirow{3}{*}{ Rank } \\
\hline & \multicolumn{2}{|c|}{ High (3) } & \multicolumn{2}{|c|}{ Moderate (2) } & \multicolumn{2}{|c|}{ Low (1) } & & & \\
\hline & $f$ & $\%$ & $f$ & $\%$ & $f$ & $\%$ & & & \\
\hline Seeds & 132 & 100 & 0.0 & 0.0 & 0.0 & 0.0 & 3.0 & 0.00 & 1 \\
\hline Veterinary pharmacy (vaccinations, drugs) & 131 & 99.2 & 1.0 & 0.8 & 0.0 & 0.0 & 2.99 & 0.08 & 2 \\
\hline Pesticides & 130 & 98.5 & 2.0 & 1.5 & 0.0 & 0.0 & 2.98 & 0.12 & 3 \\
\hline Irrigation supplies & 125 & 94.7 & 7.0 & 5.3 & 0.0 & 0.0 & 2.95 & 0.22 & 4 \\
\hline Chemical fertilizers & 124 & 93.9 & 8.0 & 6.1 & 0.0 & 0.0 & 2.94 & 0.24 & 5 \\
\hline Training sessions & 116 & 87.9 & 16 & 12.1 & 0.0 & 0.0 & 2.88 & 0.32 & 6 \\
\hline Micro-nutrients & 62 & 47 & 68 & 51.5 & 2.0 & 1.5 & 2.45 & 0.52 & 7 \\
\hline Animal feed additives & 63 & 47.7 & 65 & 49.2 & 4.0 & 3.0 & 2.45 & 0.55 & 8 \\
\hline Refrigerated trucks & 52 & 39.4 & 77 & 58.3 & 3.0 & 2.3 & 2.37 & 0.53 & 9 \\
\hline $\begin{array}{l}\text { Handling farm products (processing, sort- } \\
\text { ing, grading }\end{array}$ & 7.0 & 5.3 & 115 & 87.1 & 10 & 7.6 & 1.98 & 0.36 & 10 \\
\hline Pesticide residue testing & 5.0 & 3.8 & 117 & 88.6 & 10 & 7.6 & 1.96 & 0.33 & 11 \\
\hline New agricultural information & 13 & 9.8 & 89 & 67.4 & 30 & 22.7 & 1.87 & 0.55 & 12 \\
\hline Workshops/ seminars & 4.0 & 3.0 & 104 & 78.8 & 24 & 18.2 & 1.85 & 0.43 & 13 \\
\hline Agricultural machinery & 6.0 & 4.5 & 99 & 75 & 27 & 20.5 & 1.84 & 0.47 & 14 \\
\hline Marketing information & 9.0 & 6.8 & 53 & 40.2 & 70 & 53 & 1.54 & 0.62 & 15 \\
\hline Exhibitions/ festivals & 1.0 & 0.8 & 28 & 21.2 & 103 & 78 & 1.23 & 0.43 & 16 \\
\hline Cold storage & 0.0 & 0.0 & 0.0 & 0.0 & 132 & 100 & 1.0 & 0.00 & 17 \\
\hline Facilitates to access loans and credits & 0.0 & 0.0 & 0.0 & 0.0 & 132 & 100 & 1.0 & 0.00 & 18 \\
\hline
\end{tabular}

Source: Field survey, 2018

Table 03: Famer's satisfaction level towards the role of Unaizah Agricultural Cooperative Association in providing agricultural services.

\begin{tabular}{|c|c|c|c|c|c|c|c|c|c|}
\hline \multirow{3}{*}{ Services } & \multicolumn{6}{|c|}{ Satisfaction level } & \multirow{3}{*}{ Mean } & \multirow{3}{*}{$\mathrm{SD}$} & \multirow{3}{*}{ Rank } \\
\hline & \multicolumn{2}{|c|}{ High (3) } & \multicolumn{2}{|c|}{ Moderate (2) } & \multicolumn{2}{|c|}{ Low 1) } & & & \\
\hline & $f$ & $\%$ & $f$ & $\%$ & $f$ & $\%$ & & & \\
\hline Seeds & 125 & 94.7 & 7.0 & 5.3 & 0.0 & 0.0 & 2.9 & 0.22 & 1 \\
\hline Training sessions & 119 & 90.2 & 13 & 9.8 & 0.0 & 0.0 & 2.9 & 0.29 & 1 \\
\hline Veterinary pharmacy (vaccinations, drugs) & 114 & 86.4 & 18 & 13.6 & 0.0 & 0.0 & 2.86 & 0.34 & 2 \\
\hline Pesticides & 104 & 78.8 & 28 & 21.2 & 0.0 & 0.0 & 2.79 & 0.41 & 3 \\
\hline Irrigation supplies & 94 & 71.2 & 38 & 28.8 & 0.0 & 0.0 & 2.71 & 0.45 & 4 \\
\hline Chemical fertilizers & 70 & 53 & 62 & 47 & 0.0 & 0.0 & 2.53 & 0.50 & 5 \\
\hline Refrigerated trucks & 65 & 49.2 & 62 & 47 & 5.0 & 3.8 & 2.45 & 0.57 & 6 \\
\hline Animal feed additives & 55 & 41.7 & 69 & 52.3 & 8.0 & 6.1 & 2.36 & 0.59 & 7 \\
\hline Pesticide residue testing & 38 & 28.8 & 88 & 66.7 & 6.0 & 4.5 & 2.24 & 0.52 & 8 \\
\hline Workshops/seminars & 32 & 24.2 & 98 & 74.2 & 2.0 & 1.5 & 2.23 & 0.45 & 9 \\
\hline New agricultural information & 31 & 23.5 & 92 & 69.7 & 9.0 & 6.8 & 2.17 & 0.52 & 10 \\
\hline Micro-nutrients & 29 & 22 & 83 & 62.9 & 20 & 15.2 & 2.07 & 0.60 & 11 \\
\hline $\begin{array}{l}\text { Handling farm products (processing, sort- } \\
\text { ing, grading) }\end{array}$ & 17 & 12.9 & 102 & 77.3 & 13 & 9.8 & 2.03 & 0.47 & 12 \\
\hline Exhibitions/festivals & 26 & 19.7 & 76 & 57.6 & 30 & 22.7 & 1.97 & 0.65 & 13 \\
\hline Marketing information & 25 & 18.9 & 67 & 50.8 & 40 & 30.3 & 1.89 & 0.69 & 14 \\
\hline Agricultural machinery & 8.0 & 6.1 & 83 & 2.9 & 41 & 31.1 & 1.75 & 0.55 & 15 \\
\hline Cold storage & 0.0 & 0.0 & 0.0 & 0.0 & 132 & 100 & 1.0 & 0.00 & 16 \\
\hline Facilitates to access loans and credits & 0.0 & 0.0 & 0.0 & 0.0 & 132 & 100 & 1.0 & 0.00 & 17 \\
\hline
\end{tabular}

Scale: 1=low, 2=moderate, 3=high. Source: Field survey, 2018 


\section{Satisfaction level of the respondents regarding the services provided by Unaizah Agricultural Cooperative Association (UACA)}

Table 03 shows the respondents' satisfaction level for services provided by the UACA. The findings indicate that the farmers were highly satisfied with the following services: seeds (Mean 2.9, SD 0.22), training sessions (Mean 2.9, SD 0.29), veterinary pharmacy (Mean 2.86, SD 0.34), pesticides (Mean 2.79, SD 0.41 ), irrigation supplies (Mean 2.71, SD 0.45), chemical fertilizers (Mean 2.53, SD 0.50), and refrigerated trucks (Mean 2.45, SD 0.57). They showed moderate satisfaction levels for services like animal feed additives, pesticide residue testing, workshops/seminars, new agricultural information; micro-nutrients, handling farm products, exhibitions/festivals; marketing information; and agricultural machinery. Table 03 also reveals that that the farmers were not satisfied with the following services: cold storage facilities (Mean 1.0, SD 0.00) and availability of loans (Mean 1.0, SD 0.00).

Previous research conducted by Nishi and Kumar (2011) in India revealed that most farmers $(51.25 \%)$ were moderately satisfied with the performance of the Dairy Cooperative. Almost one-third of the member farmers $(33.75 \%)$ had high satisfaction with the services, whereas $15 \%$ of members had low satisfaction levels. The high satisfaction reflects the good performance of the Cooperative, while dissatisfaction depicts the prevalence of mismanagement in dairy Cooperative societies.

Present study revealed that $47 \%$ of the respondents were highly satisfied with agricultural services provided by the UACA. In addition, $53 \%$ of the respondents were moderately satisfied with agricultural services indicating that the farming community in Unaizah was highly satisfied regarding the role of UACA. Masango (2015) mentioned that cooperatives should enact the following principles to keep high satisfaction high among farmers: diversity services provided, implement collective activities, keep good relations with members, and practice good management.

\section{CONCLUSIONS}

This study revealed that small-scale farmers can increase their productivity and income by collectively negotiating better prices for inputs like seeds, fertilizers, and transport through cooperatives. The study revealed that majority of the respondents $(66 \%)$ had membership in the UACA for more than 20 years. However, $17 \%$ of the respondents were members of the association for less than 10 years and 17\% of them were members from 10 to 20 years. The main areas which were highly valued by the respondents were: supplying agricultural innovations at suitable prices for farmers; establishing good contacts with governmental extension staff to solve members' agricultural problems (Mean 2.67; SD 0.51); supplying agricultural information at a suitable time for farmers (Mean 2.61; SD 0.53); maintaining good relations with members (Mean 2.59; SD 0.56 ); establishing good agreements with traders to buy crops and helping members in accessing markets. In general, the results showed that the overall opinion of the respondents regarding the UACA's role was high (Mean 2.67; SD 0.53).

The results also showed that farmers had high access to services like seeds, veterinary pharmacy, pesticides, irrigation supplies, chemical fertilizers, training sessions, micronutrients and animal feed additives. The mean value for overall access was 2.41, suggesting that the farming community in Unaizah had high access to agricultural services delivered by the UACA.

Nearly one-half (47\%) of the respondents were highly satisfied with agricultural services provided by Agriculture Cooperative association, while $53 \%$ of the respondents were moderately satisfied. The farming community in Unaizah was highly satisfied regarding the role of the UACA in providing agricultural services.

\section{RECOMMENDATIONS}

Based on the empirical findings of this study, the following recommendations to the board 
members of the UACA would help them further improve and refine their work:

- The majority of the farmers moderately agree that the UACA has a role in supplying agricultural production requirements to farmers at a suitable time. However, the cooperative needs to coordinate with the private sector in order to provide farm input supplies before the farmers start undertaking agricultural practices.

- Training sessions organized by the cooperative are moderately important to farmers. However, an assessment of the training sessions by the cooperative would further help to launch improved and more beneficial future training programs.

- Members of the cooperative moderately participate in its agricultural activities. However, if dates of the meeting are set after consulting with the members and these dates of the meetings are widely circulated, it would create awareness for the importance of these activities. Employing different Information Communication Technologies (ICTs) would ensure and further enhance farmer participation.

- Farmers were not satisfied with their access to cold storage facilities and loans. The cooperative needs to coordinate with agricultural development funders to facilitate loans to the members. At the same time, concerted and immediate efforts need to take place in establishing cold storage so that members can keep their produce fresh and increase its shelf life. This might need assistance from the government.

\section{ACKNOWLEDGMENT}

The authors are extremely thankful to the Saudi Society of Agricultural Sciences, King Saud University, Saudi Arabia for all the support.

\section{REFERENCES}

Argaw, Y. A. 2007. The role of Agricultural cooperatives in accessing input and output market: An overview of experiences of SRFCF, Southern Region Farmers' Cooperative Federation. SNNPR, Ethiopia.1-5.

Al-Oifi, B. 2012. An Evaluative study for the agricultural activities provided by multi-purpose cooperative association in Al-Madīnah al-Munawarah. MSc thesis, King Saud University.

Birthal, P.S., Joshi, P.K. \& Gulati, A. 2005. Vertical coordination in high-value food commodities: Implications for smallholders. MTID discussion paper no. 85, IFPRI. Available from: http:// www.ifpri.org/divs/mtid/dp/papers/mtidp85.pdf.

Clegg, J. 2006. Rural cooperatives in China: Policy and practice. Journal of small business and Enterprise Development, 13(2), 219-234. DOI: https://doi.org/10.1108/14626000610665926

Dakurah, H.A., Goddard, E. and Osuteye, N. 2005. Attitudes towards and satisfaction with cooperatives in Alberta: A Survey analysis. American Agricultural Economics Association Annual Meeting, Providence, Rhode Island, July 24-27.

Fiaz, S., Noor, M.A. \& Aldosri, F.O. 2018. Achieving food security in the Kingdom of Saudi Arabia through innovation: Potential role of agricultural extension. Journal of the Saudi Society of Agricultural Sciences, 17(4), 365-375. DOI: https://doi.org/10.1016/j.jssas.2016.09.001

Ganpat, W. G., Webster, N. \&Narine, L. K. 2014. Farmers' satisfaction with extension services in the organization of Eastern Caribbean States, Journal of International Agricultural and Extension Education, 21(3), 49-62. DOI: https://doi.org/10.5191/jiaee.2014.21304 
General Authority for Statistics. 2018. Demographic Survey. Retrieved from https://www.stats. gov.sa/sites/default/files/en-demographic-research-2018_2.pdf

Kalim, M. 2014. Saudi Arabia country profile. Global Forum for Rural Advisory Services (GFRAS). Retrieved from: http:/g-fras.org/en/events/gfras-events/130-world-wide-extension-study/ asia/western-asia/317-saudi-arabia.html\#extension-providers

Kodama, Y. 2009. The effects of Fair Trade on coffee producers: a case study of Ethiopian coffee cooperatives. In 16th International Conference of Ethiopian Studies (pp. 297-299).

Ministry of Labor and Social Development. 2018. Cooperatives in the Kingdom of Saudi Arabia. Retrieved from http://saudigazette.com.sa/article/544098

Mohamed, F.A. 2004. Role of cooperatives in agricultural development: The case of Menofiya Governate, Egypt. Unpublished Ph.D. thesis, Faculty of Land Development. Rheinische Friedrich-Wilhelm University, Germany.

Mohamed, M. E. 2006. Access to extension services by agricultural cooperatives members and nonmembers in Khartoum state: A comparative study, Master thesis, University of Khartoum.

Masango, R. 2015. Assessing the performance of smallholder farmer cooperatives-a member's perspective: A case study of Mogalakwena Municipality (Limpopo Province). Doctoral dissertation, University of the Free State, South Africa.

Nishi, A. K. and Kumar, R. 2011. Dairy Farmers' Satisfaction with Dairy Cooperative Societies: A Case Study. Indian Res. J. Ext. Edu., 11(1), 74-78.

Shiferaw, B., Obare, G. \& Muricho, G. 2006. Rural institutions and producer organizations in imperfect markets: experiences from producer marketing groups in semi-arid Eastern Kenya. Paper presented at the research workshop on collective action and market access for smallholders, Cali, Columbia, 2-5 October. DOI: https://doi.org/10.9783/9780812207873.110

Unaizah Agricultural Cooperative Association. 2018. About the association. Retrieved from: https://agrcoop.com/?r=pages\&id=1.

Wikipedia 2017. Governorate of Unaizah. Retrieved from https://en.wikipedia.org/wiki/Unaizah. 